\title{
Breeding of Carnations (Dianthus caryophyllus L.) for Long Vase Life and Rapid Decrease in Ethylene Sensitivity of Flowers after Anthesis
}

\author{
Takashi Onozaki*, Natsu Tanikawa, Masafumi Yagi, Hiroshi Ikeda**, \\ Katsuhiko Sumitomo and Michio Shibata \\ National Institute of Floricultural Science (NIFS), National Agriculture and Bio-oriented Research Organization (NARO), \\ Tsukuba 305-8519, Japan
}

\begin{abstract}
Genetic improvement of flower vase life is an important breeding target. A breeding program aimed to improve the vase life of carnations (Dianthus caryophyllus L.) that carried out by repeatedly crossing and selecting promising progenies was effective. Thus, we developed many carnation lines with extremely long vase life by using the conventional cross-breeding technique. Selected lines from second-, third- and fourthgeneration have vase lives that are 2.7 to 4.1 times longer than the control cultivar, 'White Sim'. The mean vase life of line 108-44 was 23.6 days in 2003 and 19.1 days in 2004 (414\% and 341\% of 'White Sim' flower longevity, respectively). All selected lines showed low ethylene production in whole flowers during senescence. In addition, the petals and the gynoecia of three selected lines 908-46, 702-21, and 006-13, produced only trace amounts of ethylene during senescence, indicating that the ethylene biosynthesis pathway in these lines was almost completely blocked during senescence. Although ethylene sensitivity of the selected lines was generally high on day 0 , immediately after harvesting, ethylene sensitivity after anthesis rapidly decreased with age in the three selected lines. These lines became completely ethylene-insensitive or showed low sensitivity at the end of senescence. Autocatalytic ethylene production by the gynoecia and petals of the three selected lines also decreased on days 3 and 6, respectively, after harvest.
\end{abstract}

Key Words: carnation, ethylene production, ethylene sensitivity, flower longevity, flower senescence.

\section{Introduction}

The vase life of cut flowers is one of the most important characteristics in determining their quality and satisfying consumer preferences. Carnation (Dianthus caryophyllus L.) is one of the main floricultural crops in Japan. Senescence of its flowers is normally characterized by a climacteric-like pattern of ethylene production; that is, by a surge in ethylene production followed by a decline (Mayak and Tirosh, 1993). The increase in ethylene production is associated with the development of inrolling symptoms in flower petals and subsequent wilting (Halevy and Mayak, 1981). Carnation flowers are highly sensitive to exogenous ethylene (Woltering and Van Doorn, 1988). Hence, ethylene is an important determinant of flower longevity because it induces wilting of petals and autocatalytic ethylene production (Halevy and Mayak, 1981).

Received; July 28, 2005. Accepted; October 12, 2005.

This work was supported by a Grant-in-Aid from the Ministry of Agriculture, Forestry and Fisheries of Japan.

* Corresponding author (E-mail: onozaki@affrc.go.jp).

** Present address: National Agricultural Research Center for Kyushu Okinawa Region (KONARC), National Agriculture and Biooriented Research Organization (NARO), Kurume 839-8503, Japan.
Although the vase life of carnations is about 5-7 days in normal Sim-type cultivars, it can be extended by postharvest chemical treatments. The onset of flower senescence can be significantly delayed by treatment with inhibitors of ethylene biosynthesis, such as aminooxyacetic acid (Fujino et al., 1980), aminoethoxyvinyl glycine (Baker et al., 1977), and $\alpha$-aminoisobutyric acid (AIB) (Onozaki and Yamaguchi, 1992; Onozaki et al., 1998), or with inhibitors of ethylene action, such as silver thiosulfate (STS) (Veen, 1979) and 1-methylcyclopropene (Serek et al., 1995). In particular, STS is widely used by commercial carnation producers to extend the vase life of cut flowers because of its outstanding effectiveness. However, concerns about potential contamination of the environment from waste STS solutions have increased in recent years, so that alternative methods for improving the vase life of carnations must be developed. It would be desirable to improve genetically the vase life of carnation flowers, as the improved cultivars would require no chemical treatment to attain longer vase life. Therefore, a research breeding program was started at the National Institute of Floricultural Science, Japan, in 1992 to improve the vase life of carnation flowers by means of conventional breeding techniques. In a previous paper, we described the development of many carnation lines with increased vase life as a result of reduced ethylene biosynthesis or 
sensitivity by means of crossing and selection until second generation (Onozaki et al., 2001). In this paper, we report the results of further crossing and selection over three generations to improve the vase life of carnation flowers by using our previously selected lines as parental material. We also investigated ethylene production and sensitivity in selected lines with a long vase life.

In an earlier study, we developed a simple, accurate method for evaluating the ethylene sensitivity of carnation flowers and showed that this characteristic decreased after anthesis with age in normal Sim-type carnations (Onozaki et al., 2004). However, our understanding of age-related changes in ethylene sensitivity and autocatalytic ethylene production after anthesis in carnations with long vase life is unclear. Therefore, we are continuing to investigate changes in both factors from anthesis to senescence in three lines with a long vase life.

\section{Materials and Methods}

\section{Crossing and selection}

To improve the vase life of carnation flowers, we repeatedly crossed and selected promising progenies for three generations, from 1997 to 2004. In a previous study, we described the breeding process for these three generations from which we screened 39 lines with a long vase life (Onozaki et al., 2001). Of 39 lines 12 selected first-generation lines and 14 selected second-generation lines were chosen as parental stocks for further hybridization.

Seeds from crosses made in the spring of 1997 among 12 selected first-generation lines were harvested and sown on 24 June 1997; the seedlings were grown in a greenhouse. Progenies that did not flower until 20 May 1998 (the last day of our evaluation) were discarded. We called the 235 progenies that flowered the second generation. In June 1998, 55 progenies with the longest mean vase life ( $\geqq 11.0$ days) were selected, from which six to eight rooted cuttings for each selection were made. In 1999, 6 lines out of the 55 progenies with the longest mean vase life were selected (the "selected secondgeneration lines"). In the spring of 1998, 1999 and 2000, crosses were made with these 6 lines and the previous 14 selected second-generation lines, described in a previous paper (Onozaki et al., 2001). Seeds from these crosses were sown on 30 June 1998, 22 June 1999, and 27 June 2000 and grown. Progenies that did not flower until 21 May 1999, 24 May 2000, and 21 May 2001 (the last day of our evaluation) were discarded. We called the 181 progenies that flowered the third generation. In June of 1999, 2000 and 2001, the 56 progenies with the longest mean vase life ( $\geqq 10.2,11.3$, or 13.3 days, respectively) were selected and vegetatively propagated. In 2000, 2001 and 2002, out of the 56 progenies, we secondarily selected 17 lines with the longest mean vase life (the "selected third-generation lines"). In the spring of 2000, 2001 and 2002, crosses were made among 16 of the 17 lines. Seeds obtained were sown on 27 June 2000, 26 June 2001, and 19 June 2002 and allowed to flower in the greenhouse. Progenies that did not flower until 21 May 2001, 27 May 2002, or 30 April 2003 (the last day of our evaluation) were discarded. We called the 217 progenies that flowered the fourth generation. On June 2001, June 2002, or May 2003, 87 with the longest mean vase life ( $\geqq 13.3,14.5$, or 18.0 days) were selected and multiplied vegetatively. In 2002, 2003 and 2004, 28 lines out of 87 progenies with the longest mean vase life were secondary-selected (the "selected fourthgeneration lines").

From the above selection process, 23 out of 51 selected second-, third- and fourth-generation lines were finally considered superior for testing; one selected secondgeneration lines, eight selected third-generation lines and fourteen selected fourth-generation lines.

\section{Vase life evaluation}

Carnation cultivars or lines were grown in a greenhouse by following standard production methods and harvested at commercial maturity (i.e., when the outer petals were horizontal). Stems of the freshly harvested flowers were cut to $50 \mathrm{~cm}$, and the two lowest pairs of leaves removed. The flowers were then placed randomly in 4-L jars containing about $1000 \mathrm{~mL}$ of distilled water. The water was replaced every 3 or 4 days.

The vase life of each flower was determined by the number of days from harvesting until the petals showed in-rolling or browning and otherwise lost their ornamental value. Flowers were evaluated daily in a temperature-controlled room with a constant air temperature of $23^{\circ} \mathrm{C}, 70 \% \mathrm{RH}$, and a 12 -h photoperiod (08:00 to $20: 00 \mathrm{~h})$ provided by cool fluorescent lamps $\left(10 \mu \mathrm{mol} \cdot \mathrm{m}^{-2} \cdot \mathrm{s}^{-1}\right.$ irradiance $)$.

In the seedling trials, all harvested flowers were evaluated for vase life. For each selected line, 7-13 flowers were cut, and the mean vase life was determined (clonal test). Cut flowers of 'White Sim', 'Nora', 'Excerea', 'Francesco', 'Sandrosa', and 'Chinera' served as the standard control for comparison. The vase life of selected second- and third-generation lines was evaluated in 2001 and 2002, and that of selected fourth-generation lines was evaluated in 2003 and 2004.

\section{Video evaluation of ethylene sensitivity}

Ethylene sensitivity was measured by using a timelapse video recording system, as described previously (Onozaki et al., 2004).

To conduct a detailed examination of changes in ethylene sensitivity and autocatalytic ethylene production in lines with a long vase life during flower aging, one selected second-generation line (702-21) and two selected third-generation lines (908-46 and 006-13) were chosen. These three lines showed very high flower quality and adequate yields of cut flowers for commercial 
production, in addition to a long vase life. Thus, they will be registered as new cultivars. For the experiments with flowers of different ages, we cut the stems of freshly harvested flowers to $20 \mathrm{~cm}$ on day 0 and placed them individually in $100-\mathrm{mL}$ Erlenmeyer flasks containing distilled water. The flowers were aged under standard conditions for $0,3,6,9,12,15$, or 18 days, then continuously exposed to $10 \mu \mathrm{L} \cdot \mathrm{L}^{-1}$ of ethylene at $23 \pm 1{ }^{\circ} \mathrm{C}$ in the chamber by injecting pure ethylene gas. The time to the beginning of petal in-rolling of the flowers was determined according to Onozaki et al. (2004). The ethylene-containing air in the chamber was renewed daily after the start of treatment to avoid marked changes in the gas composition. When flowers did not wilt after more than $72 \mathrm{~h}$ of exposure, we defined them as ethylene-insensitive (no response). Data were presented as the means $\pm \mathrm{SE}$ of five flowers.

\section{Measurement of whole-flower ethylene production}

To compare the ethylene production during flower senescence, measurements were taken when senescence symptoms first appeared. Flowers of 4 cultivars and 23 lines were harvested at commercial maturity and their stems shortened to $5 \mathrm{~cm}$ and placed individually in a test tube containing distilled water. Flowers were held under standard conditions until petals showed in-rolling or browning and lost their ornamental value. When senescence was first observed, individual flowers were weighed (fresh weight), then enclosed in a glass jar and held at $23^{\circ} \mathrm{C}$. After a $1-\mathrm{h}$ incubation, a $0.5-\mathrm{mL}$ sample of the headspace gas was withdrawn and injected into a gas chromatograph (model GC-7A, Shimadzu, Kyoto, Japan) equipped with an alumina column and a flame ionization detector to determine the ethylene concentration. Data were presented as means $\pm \mathrm{SE}$ of the data for five flowers.

Measurement of ethylene production from petals and gynoecia during senescence after or without ethylene treatment

On day 0 , the stems of freshly harvested flowers of 'Francesco', 'Excerea' and 702-21, 908-46, 006-13 were cut to $20 \mathrm{~cm}$ and placed individually in $100-\mathrm{mL}$ Erlenmeyer flasks containing distilled water. The numbered selections were held for $0,3,6,9,12,15$, and 18 days, while those of 'Francesco' and 'Excerea' were kept for 0,3 , and 6 days and 0 and 3 days, respectively. The flowers were then exposed to either 0 or $2 \mu \mathrm{L} \cdot \mathrm{L}^{-1}$ of ethylene for $16 \mathrm{~h}$ at $23 \pm 1^{\circ} \mathrm{C}$ in the chamber. Ethylene production by the control (ethylene-free) 'Francesco' and 'Excerea' during senescence was measured daily. After treatment, the flowers were left for $8 \mathrm{~h}$ under standard conditions. The flowers were then separated by hand into the gynoecium (ovary plus styles) and petals. The gynoecium and the two outer petals of each flower were individually enclosed in $7-\mathrm{mL}$ glass jars and incubated at $23^{\circ} \mathrm{C}$. After a 30 -min incubation, a $0.5-\mathrm{mL}$ sample of the headspace gas was withdrawn and analyzed for ethylene concentration as above. Data were presented as the means $\pm \mathrm{SE}$ of the data for five replications.

\section{Results}

\section{Crossing and selection}

The frequency distributions for vase life in the second, third, and fourth generations were continuous normal distributions (Fig. 1). Variation was relatively small in the second generation $(\mathrm{SD}=2.27)$, but was larger in the fourth generation $(\mathrm{SD}=3.71)$. The frequencies of flowers with superior vase life (14 days or more) were $3.8 \%$ and $10.5 \%$ in the second and third generations, respectively, but rose to $61.3 \%$ in the fourth generation. The proportion of flowers with inferior vase life (4 to 8 days) decreased markedly in the fourth generation. The population mean for vase life increased by 0.7 days from the second to the third generation and by 4.2 days between the third and the fourth generations.

\section{Vase life of cultivars and selected lines}

The 6 cultivars and 23 selected lines exhibited a wide
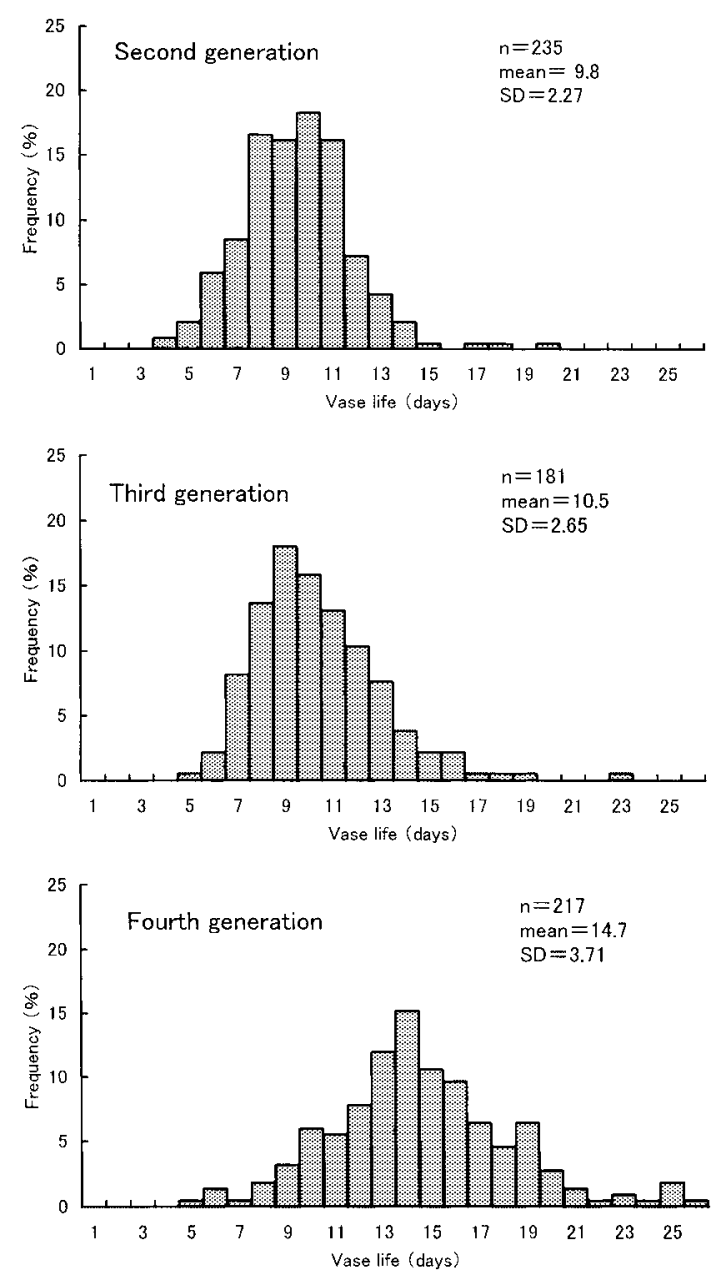

Fig. 1. Frequency distribution for vase life in the second, third, and fourth generations. 
range of variation in mean vase life (Tables 1 and 2). The mean vase life of 'White Sim', the control cultivar in many studies of flower senescence in carnation, was
5.6-6.0 days, whereas that of 23 selected lines was 2.7 times longer in two independent experiments. The mean vase life of line 108-44 was 23.6 days in 2003 and 19.1

Table 1. Flower vase life and ethylene sensitivity (day 0) of carnation cultivars and selected second- and third-generation lines under standard conditions.

\begin{tabular}{|c|c|c|c|c|c|}
\hline \multirow{2}{*}{ Cultivar or selected line } & \multicolumn{2}{|c|}{2001} & \multicolumn{2}{|c|}{2002} & \multirow{2}{*}{$\begin{array}{l}\text { Response time to ethylene } \\
\text { treatment }(\mathrm{h})\end{array}$} \\
\hline & Vase life (days) & $\%^{\mathrm{z}}$ & Vase life (days) & $\%^{\mathrm{z}}$ & \\
\hline \multicolumn{6}{|l|}{ Control cultivars } \\
\hline White Sim & $6.0 \pm 0.3$ & 100 & $5.8 \pm 0.3$ & 100 & $6.9 \pm 0.3$ \\
\hline Sandrosa & $9.9 \pm 0.9$ & 165 & $11.5 \pm 0.7$ & 198 & $6.0 \pm 0.3$ \\
\hline Chinera & not tested & & $11.1 \pm 0.7$ & 191 & $14.2 \pm 0.6$ \\
\hline \multicolumn{6}{|l|}{ Selected second-generation line } \\
\hline $702-21$ & $17.8 \pm 0.8$ & 297 & $20.2 \pm 1.3$ & 348 & $8.2 \pm 0.2$ \\
\hline \multicolumn{6}{|l|}{ Selected third-generation line } \\
\hline $85-11$ & $20.8 \pm 1.2$ & 347 & $18.5 \pm 1.4$ & 319 & $8.6 \pm 0.8$ \\
\hline $81-8$ & $18.6 \pm 1.1$ & 310 & $17.3 \pm 0.9$ & 298 & $8.0 \pm 1.0$ \\
\hline $925-6$ & $21.5 \pm 1.5$ & 358 & $20.7 \pm 1.8$ & 357 & $6.5 \pm 0.3$ \\
\hline $908-46$ & $20.0 \pm 1.4$ & 333 & $18.0 \pm 0.7$ & 310 & $6.8 \pm 0.2$ \\
\hline $903-45$ & $18.9 \pm 1.1$ & 315 & $16.6 \pm 0.5$ & 286 & $7.5 \pm 0.3$ \\
\hline $908-43$ & $18.2 \pm 1.7$ & 303 & $16.6 \pm 1.2$ & 286 & $7.0 \pm 0.6$ \\
\hline $908-44$ & $18.0 \pm 1.6$ & 300 & $17.0 \pm 1.4$ & 293 & $8.0 \pm 0.6$ \\
\hline 006-13 & not tested & & $21.3 \pm 1.7$ & 367 & $8.2 \pm 0.4$ \\
\hline
\end{tabular}

Values of vase life are the means $\pm \mathrm{SE}$ of the data for 10 flowers.

Values of response time to ethylene treatment are the means \pm SE of 5 flowers.

$\mathrm{z} \%$, the percentage of the value for the control cultivar, 'White Sim'.

Table 2. Flower vase life and ethylene sensitivity (day 0) of carnation cultivars and selected fourth-generation lines under standard conditions.

\begin{tabular}{|c|c|c|c|c|c|}
\hline \multirow{2}{*}{ Cultivar or selected line } & \multicolumn{2}{|c|}{2003} & \multicolumn{2}{|c|}{2004} & \multirow{2}{*}{$\begin{array}{l}\text { Response time to ethylene } \\
\text { treatment }(\mathrm{h})\end{array}$} \\
\hline & Vase life (days) & $\%^{z}$ & Vase life (days) & $\%^{z}$ & \\
\hline \multicolumn{6}{|l|}{ Control cultivars } \\
\hline White Sim & $5.7 \pm 0.3$ & 100 & $5.6 \pm 0.3$ & 100 & $6.9 \pm 0.3$ \\
\hline Nora & $6.2 \pm 0.4$ & 109 & $6.8 \pm 0.2$ & 121 & $7.0 \pm 0.6$ \\
\hline Excerea & $6.8 \pm 0.2$ & 119 & $5.5 \pm 0.2$ & 98 & $7.6 \pm 0.2$ \\
\hline Francesco & $8.4 \pm 0.5$ & 147 & $7.7 \pm 0.2$ & 138 & $6.8 \pm 0.2$ \\
\hline Sandrosa & $9.8 \pm 0.5$ & 172 & $10.1 \pm 0.7$ & 180 & $6.0 \pm 0.3$ \\
\hline Chinera & $11.1 \pm 0.7$ & 195 & $11.1 \pm 0.6$ & 198 & $14.2 \pm 0.6$ \\
\hline \multicolumn{6}{|l|}{ Selected fourth-generation line } \\
\hline $103-50$ & $19.4 \pm 0.7$ & 340 & $16.1 \pm 0.6$ & 288 & $8.4 \pm 0.5$ \\
\hline $104-1$ & $18.2 \pm 0.6$ & 319 & $15.3 \pm 0.4$ & 273 & $7.2 \pm 0.8$ \\
\hline $104-3$ & $21.9 \pm 0.7$ & 384 & $18.1 \pm 0.8$ & 323 & $9.8 \pm 0.7$ \\
\hline $104-6$ & $20.6 \pm 0.8$ & 361 & $16.0 \pm 0.5$ & 286 & $6.0 \pm 0.5$ \\
\hline $104-8$ & $21.1 \pm 0.5$ & 370 & $16.9 \pm 0.5$ & 302 & $10.8 \pm 0.4$ \\
\hline $104-18$ & $20.2 \pm 1.3$ & 354 & $18.0 \pm 0.8$ & 321 & $11.3 \pm 0.8$ \\
\hline $108-13$ & $21.7 \pm 1.0$ & 381 & $16.3 \pm 0.5$ & 291 & $7.6 \pm 0.3$ \\
\hline $108-14$ & $20.1 \pm 1.0$ & 353 & $16.3 \pm 0.9$ & 291 & $8.6 \pm 0.7$ \\
\hline $108-40$ & $20.5 \pm 1.4$ & 360 & $20.1 \pm 2.5$ & 359 & $7.8 \pm 0.2$ \\
\hline $108-44$ & $23.6 \pm 1.7$ & 414 & $19.1 \pm 0.7$ & 341 & $9.2 \pm 0.4$ \\
\hline $218-6$ & not tested & & $16.8 \pm 1.0$ & 300 & $6.6 \pm 0.4$ \\
\hline $220-10$ & not tested & & $18.7 \pm 1.5$ & 334 & $9.2 \pm 0.4$ \\
\hline $223-11$ & not tested & & $15.5 \pm 0.4$ & 277 & $7.4 \pm 0.5$ \\
\hline $229-1$ & not tested & & $17.7 \pm 0.6$ & 316 & $7.4 \pm 0.2$ \\
\hline
\end{tabular}

Values of vase life are the means \pm SE of the data for 7-13 flowers.

Values of response time to ethylene treatment are the means \pm SE of 5-10 flowers.

$\mathrm{z} \%$, the percentage of the value for the control cultivar, 'White Sim'. 

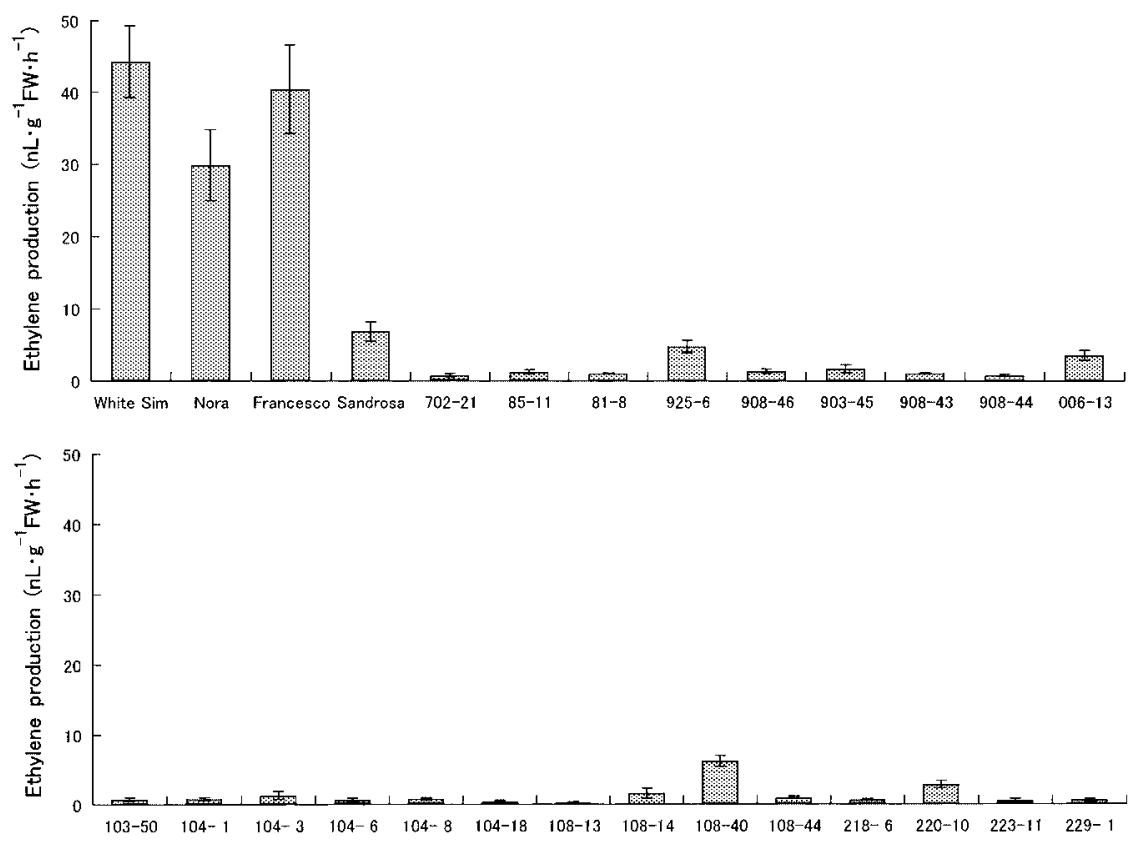

Fig. 2. Whole-flower ethylene production during senescence in 4 cultivars and 23 selected lines. Values represent the means $\pm S E$ of the data for five replications.

days in 2004 or $414 \%$ and $341 \%$ the value of 'White Sim', respectively, without chemical treatment. No selected lines showed the petal in-rolling or rapid wilting at senescence that is a typical symptom of ethylenedependent senescence. Instead, the petals faded slowly and turned brown along their edges.

\section{Ethylene sensitivity and ethylene production in the cultivars and selected lines}

The differences in ethylene sensitivity of the 6 cultivars and 23 lines on day 0 (Tables 1 and 2) revealed that 'White Sim', 'Nora', 'Excerea', 'Francesco', and 'Sandrosa' are highly sensitive with response times of 6.0 to $7.6 \mathrm{~h}$. The response times of two selections 1048 and 104-18 exceeded $10 \mathrm{~h}$, whereas that of the remaining 21 lines ranged from 6.0 to $9.8 \mathrm{~h}$. The 'Chinera', known for its low ethylene sensitivity (Wu et al., 1991), had the longest response time of $14.2 \mathrm{~h}$.

The differences in ethylene production during senescence in 4 cultivars and 23 selected lines (Fig. 2) show that 'White Sim', 'Nora', and 'Francesco' evolved a very high level of ethylene, whereas 'Sandrosa', which is known to lack a climacteric ethylene response (Mayak and Tirosh, 1993), produced little ethylene. The 23 selected lines showed extremely low ethylene production and lacked a climacteric ethylene peak (data not shown).

\section{Changes in ethylene sensitivity and in autocatalytic ethylene production during flower aging}

The response times of lines 908-46, 702-21, and 00613 to ethylene treatment on day 0 were $6.8,8.2$, and $8.2 \mathrm{~h}$, respectively (Table 1). Although these lines showed high ethylene sensitivity immediately after anthesis, as did the control cultivars except 'Chinera', that of the selected lines decreased markedly with increasing flower age (Fig. 3). In particular, selections 908-46 and 702-21 completely lost their wilting response to ethylene on and after days 12 and 18, respectively (Figs. 3 and 4), whereas 006-13 showed extremely low sensitivity on day 18 with a response time of $65.5 \mathrm{~h}$.

The levels of ethylene production from the petals and gynoecia during senescence (Fig. 5) was rapid in 'Francesco' and 'Excerea' reaching the climacteric peaks in $<9$ days. In 'Excerea', ethylene production peaked in the gynoecia earlier than in the petals, whereas that of the three selected lines (908-46, 702-21, and 006-13) produced only trace amounts of ethylene in both the petals and the gynoecia throughout the experimental period.

The levels of ethylene production from the petals and from the gynoecia after ethylene treatment (Fig. 6) reveal

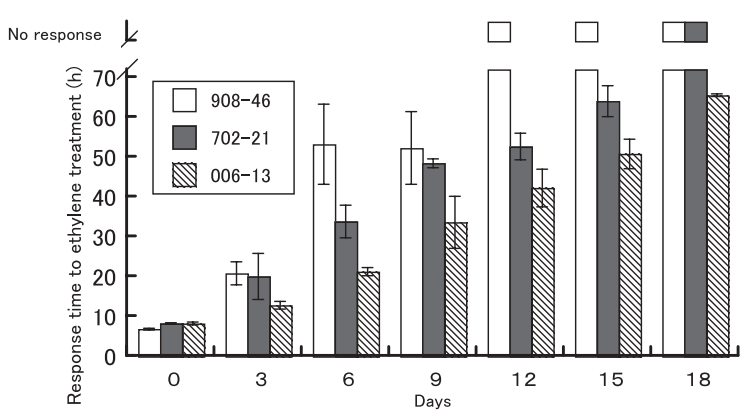

Fig. 3. Ethylene sensitivity of aging flowers of three carnation selections with long vase life. Values represent the means $\pm \mathrm{SE}$ of the data for five replications. 
A

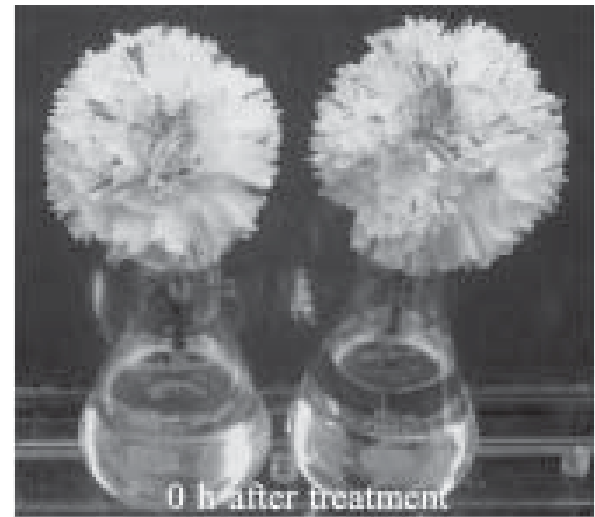

B

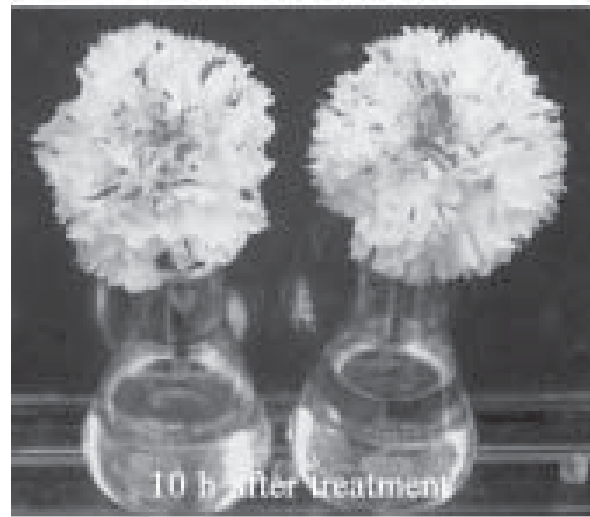

$\mathrm{C}$

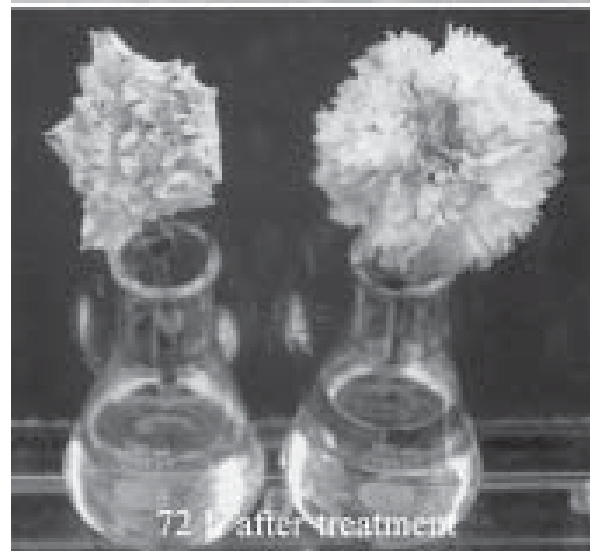

Fig. 4. Effect of cut flower age at treatment time on ethylene sensitivity of selection 702-21 flowers. A, B, and C were photographed at 0,10 , and $72 \mathrm{~h}$ after ethylene treatment began, respectively. Left: flower immediately exposed to $10 \mu \mathrm{L} \cdot \mathrm{L}^{-1}$ of ethylene after harvesting. Right: flower exposed to $10 \mu \mathrm{L} \cdot \mathrm{L}^{-1}$ of ethylene 18 days after cutting.

that exogenous ethylene applied to the carnation flowers induced autocatalytic ethylene production in both the petals and the gynoecia of all cultivars and lines. Changes in the levels of autocatalytic ethylene production differed between the petals and gynoecia. In the petals, the ethylene production of the selections remained lower than that of 'Francesco' and 'Excerea', but gradually decreased more over time. In the gynoecia, autocatalytic ethylene production was low on day 0 in all tested flowers, but subsequently it rose and reached a peak on day 3, when the gynoecia matured prior to pollination,
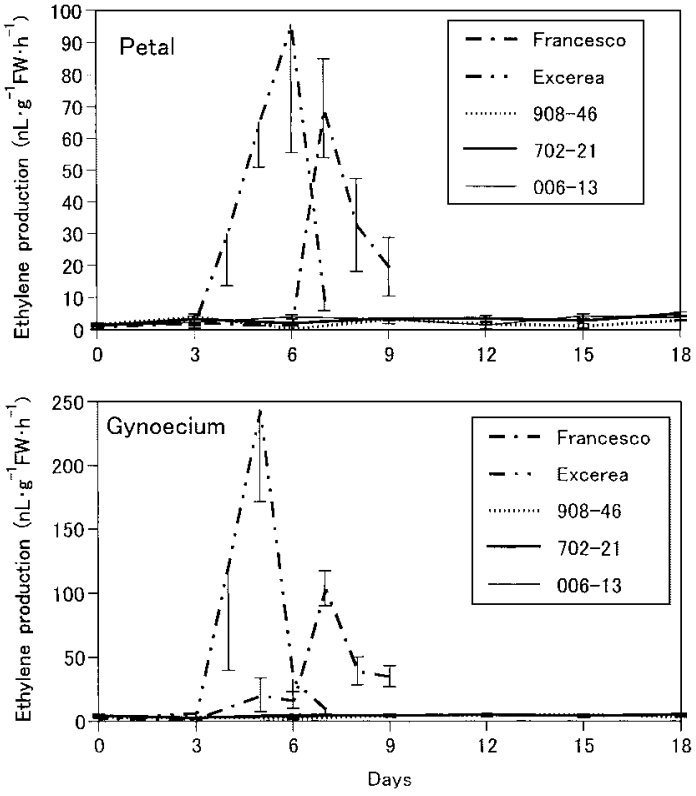

Fig. 5. Changes in ethylene production from the petals and gynoecia of two cultivars ('Francesco', 'Excerea') and three lines (90846, 702-21, 006-13) during senescence. Values represent means $\pm \mathrm{SE}$ of the data for five replications.
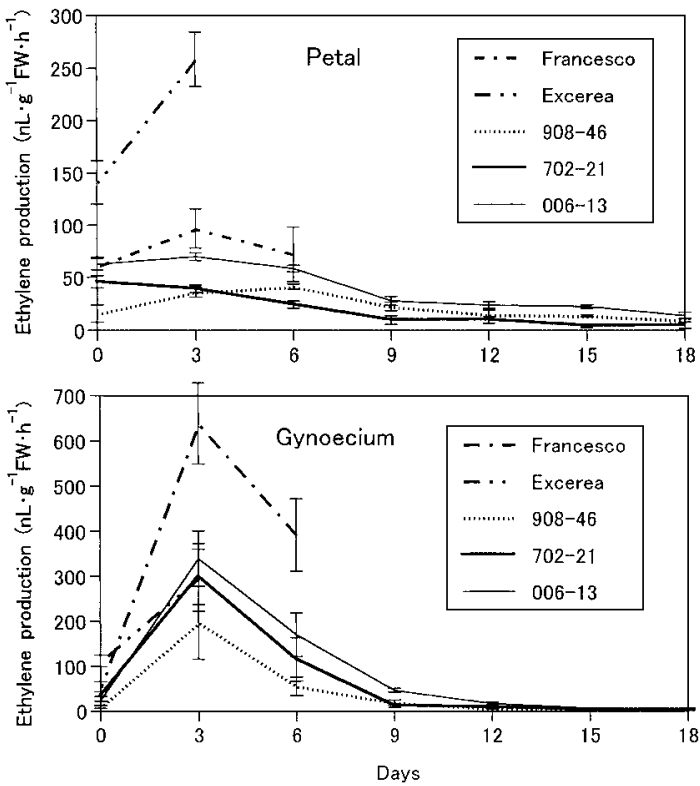

Fig. 6. Changes in ethylene production from the petals and gynoecia of 'Francesco', 'Excerea', 908-46, 702-21, and 006-13 after ethylene treatment. Flowers on day $0,3,6,9,12,15$, or 18 were treated with ethylene at $2 \mu \mathrm{L} \cdot \mathrm{L}^{-1}$ for $16 \mathrm{~h}$. Values represent means $\pm \mathrm{SE}$ of the data for five replications.

and decreased thereafter. The gynoecia of selected lines produced only trace amounts of ethylene on and after day 12 .

\section{Discussion}

The research-breeding program described in this paper began in 1992, by using six cultivars ('Pallas', 
'Sandrosa', 'Candy', 'Tanga', 'White Sim', and 'Scania') as parental materials. The mean vase life of the generation derived from crossing these six cultivars was 7.4 days (Onozaki et al., 2001); in contrast, that of the fourth generation, derived from four cycles of crossing and selection, was 14.7 days (Fig. 1), a net increase of 7.3 days. By comparison, the mean vase life of the 'Sandrosa', which had the longest vase life among the original six parental cultivars, was only $9.8-11.5$ days (Tables 1 and 2). All of the 23 selected lines showed a longer vase life than 'Sandrosa' in every year. These results indicate that by repeatedly crossing and selecting progenies based on vase life, we effectively developed selections with a longer vase life.

The flowers of the selected lines produced very low levels of ethylene during senescence (Fig. 2), whereas the ethylene sensitivity of the selected lines on day 0 was generally high (Tables 1 and 2). Thus, the long vase lives of these selected progenies are not associated with ethylene sensitivity on day 0 , but rather with their low level of ethylene production during senescence. Previously, when we screened selections 515-10, 64-13, and 64-54 with low ethylene sensitivity out of 39 lines with long vase life, 64-54 had the lowest sensitivity with a response time of $20.6 \mathrm{~h}$ to $10 \mu \mathrm{L} \cdot \mathrm{L}^{-1}$ of ethylene (Onozaki et al., 2001, 2004). In the present paper, none of the 23 lines had such a low ethylene sensitivity. The results strongly suggest that repeated crossing and selection for a longer vase life did not result in a lower ethylene sensitivity, but rather in a lower ethylene production.

The responsiveness of flower petals to ethylene varies with the physiological age and condition of the tissues at the time of exposure (Borochov and Woodson, 1989; Brown, 1997; Halevy and Mayak, 1981). Ethylene sensitivity of flowers increases with age, from anthesis to senescence in species, such as Petunia hybrida (Whitehead and Halevy, 1989), Pelargonium $\times$ domesticum (Deneke et al., 1990; Evensen, 1991), Eustoma grandiflorum (Ichimura et al., 1998), a Portulaca hybrid (Ichimura and Suto, 1998), and Torenia fournieri (Goto et al., 1999). Contrarily, we demonstrated that ethylene sensitivity after anthesis decreased with age in carnations (Onozaki et al., 2004). In this study, both the ethylene sensitivity and the autocatalytic ethylene production of three selected lines with long vase life also decreased with age (Figs. 3, 4 and 6). To determine the degree of ethylene sensitivity, when selections $85-11,81-8,925$ $6,908-43$ and $908-44$ were exposed to ethylene, they responded without exception that the sensitivity to ethylene decreased rapidly with age (data not shown). Although selected lines with long vase life were sensitive to ethylene immediately after anthesis, they became almost completely ethylene-insensitive or developed extremely low sensitivity by the end of senescence.

Genetic inhibition of either ethylene production or ethylene perception delays flower senescence. Savin et al. (1995) reported that the vase life of carnation flowers was extended by the introduction of an antisense ACC oxidase gene; the transgenic plants had a vase life of 8 to 9 days at $21^{\circ} \mathrm{C}$. Similarly, Kosugi et al. (2002) reported that cut flowers of a transgenic carnation line (the sACO1 line), which was transformed by using a carnation ACC oxidase cDNA in the sense orientation, had a longer vase life than had flowers of the non-transformed plants. Cut flowers of the sACO-1 line had a vase life of 9.5 days, versus 5.8 days for the non-transformed control line at $23^{\circ} \mathrm{C}$.

Bovy et al. (1999) reported that the vase life of carnations was also extended by the introduction of an Arabidopsis etr 1-1 gene. Their highest-performing etr 1-1 transgenic plants had a mean vase life of 24 days, nearly three times that of the control flowers $(8.3$ days $)$ at $20^{\circ} \mathrm{C}$. In contrast, our selection 108-44 exhibited a mean vase life of 23.6 days in 2003 and 19.1 days in 2004; this value amounts to 3.4-4.1 times, respectively, to the vase life of 'White Sim' at $23^{\circ} \mathrm{C}$. Thus, extending the vase life of carnation by means of conventional cross-breeding techniques appears to be highly practical approach compared with more advanced genetic engineering methods.

The breeding of cultivars with genetically superior vase life appears to be a very efficient approach for satisfying the consumer's quality expectations. A significant genetic improvement was accomplished by the fourth generation. One problem with our selections is that they are highly ethylene sensitive immediately after anthesis. To resolve this, we are currently making additional crosses between selected lines with extremely long vase life and line 64-54, which was selected previously as a very low ethylene sensitive selection (Onozaki et al., 2001). Woltering et al. (1993) have shown that reduced ethylene sensitivity is heritable so that it should be possible to breed ethylene-insensitive or less-sensitive lines by means of conventional crossbreeding techniques.

\section{Literature Cited}

Baker, J. E., C. Y. Wang, M. Lieberman and R. E. Hardenburg. 1977. Delay of senescence in carnations by rhizobitoxine analogue and sodium benzoate. HortScience 12: 38-39.

Borochov, A. and W. R. Woodson. 1989. Physiology and biochemistry of flower petal senescence. Hort. Rev. 11: $15-43$.

Bovy, A. G., G. C. Angenent, H. J. M. Dons and A. C. Van Altvorst. 1999. Heterologous expression of the Arabidopsis etr1-1 allele inhibits the senescence of carnation flowers. Mol. Breed. 5: 301-308.

Brown, K. M. 1997. Ethylene and abscission. Physiol. Plant. 100: $567-576$.

Deneke, C. F., K. B. Evensen and R. Craig. 1990. Regulation of petal abscission in Pelargonium $\times$ domesticum. HortScience 25: 937-940.

Evensen, K. B. 1991. Ethylene responsiveness changes in 
Pelargonium $\times$ domesticum florets. Physiol. Plant. 82: 409-412.

Fujino, D. W., M. S. Reid and S. F. Yang. 1980. Effects of aminooxyacetic acid on postharvest characteristics of carnation. Acta Hort. 113: 59-64.

Goto, R., R. Aida, M. Shibata and K. Ichimura. 1999. Role of ethylene on flower senescence of Torenia. J. Japan. Soc. Hort. Sci. 68: 263-268.

Halevy, A. H. and S. Mayak. 1981. Senescence and postharvest physiology of cut flowers, part 2. Hort. Rev. 3: 59-143.

Ichimura, K., M. Shimamura and T. Hisamatsu. 1998. Role of ethylene in senescence of cut Eustoma flowers. Postharvest Biol. Technol. 14: 193-198.

Ichimura, K. and K. Suto. 1998. Role of ethylene in acceleration of flower senescence by filament wounding in Portulaca hybrid. Physiol. Plant. 104: 603-607.

Kosugi, Y., K. Waki, Y. Iwasaki, N. Tsuruno, A. Mochizuki, T. Yoshioka, T. Hashiba and S. Satoh. 2002. Senescence and gene expression of transgenic non-ethylene-producing carnation flowers. J. Japan. Soc. Hort. Sci. 71: 638-642.

Mayak, S. and T. Tirosh. 1993. Unusual ethylene-related behavior in senescing flowers of the carnation Sandrosa. Physiol. Plant. 88: 420-426.

Onozaki, T., H. Ikeda and M. Shibata. 2004. Video evaluation of ethylene sensitivity after anthesis in carnation (Dianthus caryophyllus L.) flowers. Sci. Hort. 99: 187197.

Onozaki, T., H. Ikeda and T. Yamaguchi. 1998. Effect of calcium nitrate addition to $\alpha$-aminoisobutyric acid (AIB) on the prolongation of the vase life of cut carnation flowers. J. Japan. Soc. Hort. Sci. 67: 198-203.

Onozaki, T., H. Ikeda and T. Yamaguchi. 2001. Genetic improvement of vase life of carnation flowers by crossing and selection. Sci. Hort. 87: 107-120.

Onozaki, T. and T. Yamaguchi. 1992. Effect of $\alpha$ aminoisobutyric acid (AIB) application on the prolongation of the vase life of cut carnation flowers. Bull. Natl. Res. Inst. Veg. Ornam. Plants Tea Ser. A 5: 69-79 (In Japanese with English summary).

Savin, K. W., S. C. Baudinette, M. W. Graham, M. Z. Michael, G. D. Nugent, C. Y. Lu, S. F. Chandler and E. C. Cornish. 1995. Antisense ACC oxidase RNA delays carnation petal senescence. HortScience 30: 970-972.

Serek, M., E. C. Sisler and M. S. Reid. 1995. Effects of 1MCP on the vase life and ethylene response of cut flowers. Plant Growth Regulation 16: 93-97.

Veen, H. 1979. Effects of silver on ethylene synthesis and action in cut carnations. Planta 145: 467-470.

Whitehead, C. S. and A. H. Halevy. 1989. Ethylene sensitivity: the role of short-chain saturated fatty acids in pollinationinduced senescence of Petunia hybrida flowers. Plant Growth Regulation 8: 41-54.

Woltering, E. J., D. Somhorst and C. A. de Beer. 1993. Roles of ethylene production and sensitivity in senescence of carnation flower (Dianthus caryophyllus) cultivars White Sim, Chinera and Epomeo. J. Plant Physiol. 141: 329-335.

Woltering, E. J. and W. G. Van Doorn. 1988. Role of ethylene in senescence of petals - morphological and taxonomical relationships. J. Exp. Bot. 39: 1605-1616.

Wu, M. J., W. G. Van Doorn and M. S. Reid. 1991. Variation in the senescence of carnation (Dianthus caryophyllus L.) cultivars. II. Comparison of sensitivity to exogenous ethylene and of ethylene binding. Sci. Hort. 48: 108-116.

花持ちの優れるカーネーションの育種とその選抜系統の花における開花後のエチレン感受性の急速な低下

\author{
小野崎 隆・谷川奈津・八木雅史・池田 広*・住友克彦・柴田道夫 \\ 農業・生物系特定産業技術研究機構 花き研究所 305-8519 つくば市藤本
}

\begin{abstract}
切り花の花持ち性は花きの重要な育種目標であり, 著 者らは交雑育種によるカーネーションの花持ち性の改良 に関する研究を行ってきた，花持ち性向上を目指した選 抜と交配の繰り返しは，効果的であった。交雑育種によ り従来にないほどの優れた花持ち性を持つ多数のカー ネーション系統を獲得した，第 2 ，第 3 ，第 4 世代選抜 系統は，対照品種 ‘ホワイトシム’ の 2.7〜 4.1 倍の優れ た花持ち性を示した. 特に, 系統 108-44 の花持ち日数 は, 2003 年の調査では 23.6 日, 2004 年の調査では 19.1 日と, 品質保持剂処理無しで対照品種 ‘ホワイトシム’ の 3.4〜 4.1 倍の非常に優れた花持ち性を示した. 全ての 選抜系統の花は, 自然老化時に打けるエチレン生成量が 少ない傾向を示した．系統 908-46，702-21，006-13を用 いて自然老化時の器官別エチレン生成量の推移を調査し
\end{abstract}

たところ，花弁，雌ずいとも全期間を通じて極めて低レ ベルであり，自然老化時にはエチレン生合成がほぼ完全 に止まっていると考えられた。 これらの系統のエチレン 感受性は収穫直後では高いが, 花の加齢に伴い急激に低 下した. 特に, 系統 908-46 では収穫 12 日後以降, 系統 702-21 では 18 日後にはエチレン処理に対する花弁の萎 调反応が全く認められなくなった. また, 自己触媒的工 チレン生成に関しても，初期には生成能力があるが，雌 ずいでは収穫 3 日後以降, 花弁では 6 日後以降に花の加 齢に従い低下した。

\footnotetext{
* 現在 : 農業・生物系特定産業技術研究機構 九州沖 縄農業研究センター 839-8503 久留米市御井町.
} 